\title{
Integration and Informal Institutions
}

\section{Daniel Rauhut ${ }^{1}$}

Published online: 11 March 2020

(C) The Author(s) 2020

\begin{abstract}
This article offers a theoretical discussion on the role of informal institutions in the integration process of immigrants to a new country. Previous research on how immigrants become integrated and assimilated into the host countries demonstrates that integration/assimilation takes long time, often occurring over several generations; formal institutions matter; such theories are good at explaining how integration takes place, but not why integration/assimilation fails or succeeds. The informal institutions of both immigrants and native populations are examined. The discussion is based upon institutional theory in economics and political science. The findings suggest that informal institutions can explain why integration take place, and why some nationalities integrate into a new country, while others do not.
\end{abstract}

Keywords Integration $\cdot$ Informal institutions $\cdot$ Institutional theory $\cdot$ Nationality $\cdot$ Immigrants

The integration of immigrants is essentially seen as a twoway process involving the immigrants themselves and the receiving society (Penninx and Garcés-Mascareñas 2016). Many North-West European countries have left the concept of guest worker policies, which considered immigrants as only temporary residents, and moved towards integration policies that recognise immigrants as permanent residents. More recently, many countries have also adopted policies that promote and even demand immigrants' cultural assimilation in the host society (Doomernik and BruquetasCallejo 2016). Formal institutions (e.g. laws, regulations, public agencies, and organisations) facilitate integration of immigrants, and these institutions interact with the policy process in the host country (Penninx 2003; North 1991). Language proficiency and language demands on immigrants have increased (de Cillia 2012).

Several countries also display a categorisation of immigrants in their policymaking and implementation. Laws and policies explicitly and implicitly categorise immigrants as 'wanted' and 'unwanted' immigrants, or as immigrants 'in need of integration' and immigrants who are 'already integrated' or 'beyond integration'. Hence, an immigrant's integration is not only shaped by explicit integration policies, but also the

Daniel Rauhut

daniel.rauhut@uef.fi

1 Karelian Institute, University of Eastern Finland, Yliopistokatu 2, P.O. Box 111, FI-80101 Joensuu, Finland way policies explicitly and implicitly perceive, problematize and categorise them (Mügge and van der Haar 2016). In democratic countries, such categorisation in policymaking and implementation can be traced back to the opinions of the electorate and the desire of politicians to be (re) elected (Tullock 2006). Social interaction and preferences of codes of conduct, what is socially acceptable or not, and customs and traditions are determined by informal institutions in society (North 1991; March and Olsen 1986). Hence, the categorisation of immigrants in policymaking and implementation can be traced back to informal institutions in the electorate.

Informal institutions among immigrants such as religion and culture can determine the success of integration, and immigrant groups may become either an accepted part of society on the same level as comparable native groups, or they may isolate themselves or remain unrecognized and excluded (Penninx 2003). Ethnic identification appears to be strongest among the lowest and highest social classes of immigrant groups (Lee and Bean 2004; Bean and Stevens 2003), and race/ethnic identification has become more subjective among immigrants (Waters 1990). Religion appears to have a major impact on the willingness of immigrants to integrate (Polak 2012). The attitudes of natives towards immigrants also plays an influential role in how successful their integration will be (Paas and Halapuu 2012). Just as the attitudes among immigrants towards the host society (i.e. its informal institutions) influence how integrated they will be, the attitudes extended towards immigrants is also determined by informal institutions among the native population (Penninx 2003). 
However, Penninx (2003) does not discuss how these informal institutions among immigrants and natives impact upon the integration process.

Despite offering knowledge on what influence informal institutions have on society and policy making, research tends to focus on formal institutions when it comes to examining the integration of immigrants (Martone et al. 2014; Oswald 2007; Heckmann and Bosswick 2006; Kogan 2007; Huber 2014; OECD 2006; Hansen 2012). The impact of migration governance on integration has been discussed (Scholten 2016; Scholten and Penninx 2016; Scholten et al. 2016; Hoekstra et al. 2017), as has how public authorities try to shift the responsibility and costs of integration to other levels and agents (Spehar et al. 2017).

There are many theories on how immigrants become integrated and assimilated into their host countries, including the Chicago school of assimilation (Park 1950; Thomas and Znaniecki 1974), the melting pot theory (Gordon 1964: Glazier and Moynihan 1964), racial/ethnic disadvantage theory (Glazer and Moynihan 1963; Glazer 1993; Portes and Zhou 1993), and ethnic stratification and selective acculturation (Esser 2010). These theories have two things in common: (1) integration/assimilation takes a long time, often occurring over several generations; (2) the theories are good at explaining how integration takes place, but not why integration/assimilation fails.

This article aims to discuss the importance of informal institutions in the integration of immigrants to host societies from a theoretical perspective. As 'it takes two to tango', the informal institutions of both immigrants and native populations will be discussed. The theoretical point of departure here is found in institutional theory, which focuses on deeper and more resilient aspects of social structure. It considers the processes by which structures (including schemes, rules, norms and routines) become established as authoritative guidelines for social behaviour (Scott 2008).

The following research questions will be answered: (1) How is the integration process influenced by informal institutions among immigrants and natives?; (2) Is it possible to predict the integration process depending on the informal institutions of immigrants and natives?; and (3) What policy implications may an institutional approach have for integration?

\section{A Note on Methodology}

How institutions influence or even determine the integration of immigrants is an important methodological issue. This article deals with three key entities: integration, institutions and nationality. Institutions, $(J)$ determine a person's nationality $(N)$, and nationality in turn determines integration $(I)$. Institutional changes will lead to changes in perceived nationality, and changes in perceived nationality will lead to changes in the integration of immigrants. Hence, according to the chain rule for computing the derivative of the composition of two or more functions (Anton 1999), changes in institutions will lead to changes in the integration of immigrants:

$\frac{\partial N}{\partial J} x \frac{\partial I}{\partial N}=\frac{\partial I}{\partial J}$

This article generates a typology of the interplay between integration and institutions. It is a Weberian ideal-type typology, and as such, may be used as a measuring rod of reality, and a tool for systematising and comprehending individual facts against which reality can be measured. In this sense, ideal types are constructs or concepts, which are used as methodological tools in the understanding and analysis of any social problem (Rubin and Babbie 2014). However, rather than testing hypotheses, empirically testable hypotheses will be generated for use in future studies.

\section{Institutions}

It is common to distinguish between formal and informal rules or constraints, but this distinction is drawn in a variety of ways. The term formal is often taken to mean that the rules are made explicit or written down, particularly if they are enforced by the state; whereas informal rules are implicit (Kingston and Caballero 2009). Milgrom et al. (1990) argues that actors with specialised roles enforce formal rules, whereas the members of the relevant group enforce informal codes of behaviour endogenously. Informal constraints, as North (1990, 36-40) notes, include "codes of conduct, norms of behavior, and conventions" as well as "extensions, elaborations and modifications of formal rules", and "are a part of the heritage that we call culture".

When discussing integration policies, institutions - formal and informal - play an important role: institutions are the key to e.g. social inclusion, job creation, economic growth and social welfare. North $(1990,3)$ views that institutions" are the rules of the game in a society, or more formally, are the humanly devised constraints that shape human interaction", and goes on to say that they" reduce uncertainty by providing a structure to everyday life" (Ibid.). Institutions include both formal rules such as laws and constitutions, and informal constraints such as conventions and norms. March and Olsen $(1989,22)$ also emphasise the importance of rules when defining institutions, highlighting: "routines, procedures, conventions, roles, strategies, organizational forms, and technologies around which political activity is constructed. We also mean the beliefs, paradigms, codes, cultures, and knowledge that surround, support, elaborate, and contradict those rules and routines." 
Institutions of integration include the formal and informal rules around which the process of integration is constructed, drawing on the definitions provided by North (1990) and March and Olsen (1989). Institutions related to the integration of immigrants can facilitate an efficient merger, co-existence or enrichment of society between natives and immigrants. Informal institutions influence both natives and immigrants, and can stimulate or obstruct the integration process. Moreover, informal institutions determine whom the native population consider as 'one of us', and when the immigrant becomes 'one of us'. Similarly, informal institutions also determine how much immigrants want to give up of their original culture and/or how much of the influences of the new country they want to absorb. This relates to the reduction of uncertainties in every day's life, emphasised by North (1990).

\section{Integration}

There is no consensus on a single definition of integration. Definitions share commonalities but remain contextual or country specific. Nevertheless, migrant integration may be broadly defined as:

the process by which migrants become accepted into society, both as individuals and as groups. It generally refers to a two-way process of adaptation by migrants and host societies, while the particular requirements for acceptance by a host society vary from country to country. Integration does not necessarily imply permanent settlement. It does, however, imply consideration of the rights and obligations of migrants and host societies, of access to different kinds of services and the labour market, and of identification and respect for a core set of values that bind migrants and host communities in a common purpose (IOM 2011, 51).

The subjective feeling of affinity or social belonging offers an interesting theoretical point of departure when discussing problems related to integration of immigrants. The argument is simple: The more people around you are like yourself in regard to income, religion, ethnicity, age, sex, profession etc., the more you care about them, simply because you can identify yourself with them. By being concerned about their wellbeing, you also assure yourself that they will be concerned about your wellbeing if you face difficulties. A key argument is 'next time it could be me!' (Kristov et al. 1992). However, some groups never get any sympathy: namely immigrants and young adults, and in this context they are seen as being new at the labour market and have not yet proven that they are 'one of us' (Lindert 2004).

In line with the social affinity argument, the more an immigrant is different from the native population (e.g. by religion or ethnicity), the more difficult it will be for them to become 'one of us'. However, it needs to be emphasised that this is not due to racism, but due to the fact that the native population cannot identify themselves with the immigrant and vice versa. We assume this issue would have an impact on the chances of successful integration of immigrants.

\section{Nationality}

Definitions of 'nationality' are usually fuzzy, vague and ambiguous, and this is so for both objective and subjective definitions (Hobsbawm 1995). Regardless how 'nationality' is defined, it is an institution with an impact on the process of integration of immigrants. In this context, two extreme positions regarding nationality are highlighted: Smith (1996) who adopts a very conservative view on nationality, and Hobsbawm (1995) who adopts a Marxist view.

Nationality by Ethnicity, Religion and History Nationality is related to ethnicity, religion and history. It is also related to a defined territory. Smith $(1996,56-57)$ views that a nation is "a named human population which shares myths and memories, a mass public culture, a designated homeland, economic unity and equal rights and duties for all members". Moreover, he argues that national culture:

/ ... / has reasserted its primacy over politics, economics and technology, for culture is the unchanging fabric of society, with its slow rhythms of communication, its deep structures in the human psyche and its allencompassing symbolic codes and networks of social relations (Smith 1996, 53).

First, an immigrant who has no knowledge of the culture of a new country of residence, and cannot become a member of that nation unless s/he absorbs its national culture. The national culture is intertwined with e.g. the religion and history of this ethnie. Second, Smith's description of 'the national culture' and how it affects all aspects of society, communication, economy, and social relationships etc. is similar to the functioning of institutions. Third, to become a member of a new nation means that the immigrant has to adjust, or even assimilate, to the informal institutions in the new country of residence. Fourth, the immigrant already carries a national culture from their country of origin, and if the informal institutions carried from the country of origin do not permit an openness for giving them up, then adjustment in the new country of residence may be difficult.

Taking the argument one-step further, in an ethnically homogeneous community, informal institutions may require a 
bloodline to become 'one of us'. If this is the case, an immigrant will find it difficult to become integrated.

Nationality by Language and Socialisation Hobsbawm (1995) argues that 'nations' and 'nationality' are based upon the subjective feeling within a group related to e.g. a common language, common history, cultural traits and common territory.

The French insistence on linguistic uniformity since the Revolution has indeed been marked, and at the time it was quite exceptional. / ... / [I] $\mathrm{t}$ was not the native use of French language that made a person French / ... / but the willingness to acquire this, among the other liberties, laws and common characteristics of the free people of France. In a sense acquiring French was one of the full conditions of French citizenship (and therefore nationality) as acquiring English became for American citizenship (Hobsbawm 1995, 21).

The nation is a changing, evolving, modern construct that is brought into being by nationalism, and not the other way around. The ideology of nationalism rests on three invented traditions: (1) those establishing or symbolising social cohesion and collective identities; (2) Those establishing or legitimatising institutions and social hierarchies; and (3) Those socialising people into particular social contexts (Hobsbawm and Ranger 1983).

An immigrant to a new country of residence will be socialised by picking up the language, culture and common characteristics of the people, and hence integrated. Hobsbawm does not argue that the immigrant has to denounce, leave or reject his/her original nationality (which would imply assimilation), but adopt just a few key institutions in the new country of residence. These institutions will, in turn, facilitate the integration process.

\section{Integration and Nationality}

How the immigrant and the host society perceives 'nationality' is a key to understanding why the integration process is sometimes successful and sometimes fails. It is important to emphasise that the responsibility for a successful integration process lies on both the immigrant and the host society ('it takes two to tango'). Nationality is an informal institution and as with all institutions, it can obstruct or stimulate the desired development.

A first example can be made from a situation where both the nationality of the immigrant and host country is based upon ethnicity, religion and history. The host country requires that the immigrant picks up 'the national culture' and understands how it affects e.g. all aspects of society, communication, economy, and social relationships. Since nationality (as seen from the host country's perspective) is based upon ethnicity, religion and history, the immigrant has to adopt this as well. It is therefore possible to say that the host country requires assimilation from the immigrant.

The immigrant already carries a national culture from their country of origin. If the national culture is based upon ethnicity, religion and history, it will be very difficult for the immigrant to give up everything from his/her country of origin. To assimilate into a country one does not agree/ identify with will be difficult. Thus, the conclusion of this first example is that when the nationality of the immigrant and the host country is based upon ethnicity, religion and history, then integration will fail. In effect, we are not even talking about integration, but rather assimilation.

A second example can be made from a situation where the nationality of the host country is based upon ethnicity, religion and history and the one of the immigrant upon language and socialisation. Again, the host country requires an assimilation from the immigrant. In this case, however, the immigrant is willing to learn the language to become a member of the new community and access the rights and duties of the host country. This will lead to a socialisation process into the host country, but it will not lead to an assimilation. As the immigrant cannot meet the requirements of the host country, the integration will only be partial. It is partial because the immigrant will learn the language and wants to participate in the socialisation process, but, at the same time, will not assimilate as the host country requires. Hence, the immigrant will never become 'one of us', and consequently the integration will occur only in some areas (e.g. labour market, housing market etc.), so the integration will be partial.

In the third example, the situation is the opposite: the nationality of the immigrant is based upon ethnicity, religion and history, while the nationality of the host country is based upon language and socialisation. The host country require that the immigrant learns the language to enjoy the rights and duties of the new country, and shows a willingness to become socialised into the host country. However, the immigrant will find it difficult to integrate into the host country as s/he already carries a national culture from the country of origin, and this is so deeply rooted in the mind of the immigrant that adjustment is difficult. Learning a new language and being open to becoming socialised into a new country will be even more difficult if the immigrant is a refugee, whereby s/he may not even want to be in the host country in the first place. Hence, the integration will be incomplete as the immigrant does not want to participate in the socialisation process.

The last example describes a situation where both the nationality of the immigrant and host country are based upon language and socialisation. A relatively fast integration of immigrants can be expected as both parties understand what is required of them. 
This theoretical discussion is summarised in Table 1. 'It takes two to tango', and depending on whether and how the host country and the immigrants want to dance, the results of integration will differ.

\section{Relation to Other Integration Theories}

The theoretical situation labelled as 'partial integration' has been touched upon in research. The racial/ethnic disadvantage theory claims that the assimilation of many immigrant groups often remains blocked; language and cultural familiarity may often not lead to increased assimilation; lingering discrimination and institutional barriers to employment and other opportunities block complete assimilation. If immigrants compare the socioeconomic opportunities in the host country to those of their countries of origin, they may not perceive such barriers. However, by the second or third generation, they may realise that the goal of full assimilation may be more difficult and take longer than originally presumed (Glazer and Moynihan 1963; Glazer 1993; Portes and Zhou 1993; Piore 1979).

While the host country requires an assimilation from the immigrant, the immigrant is often willing to learn the language to become a member of the new community. Through doing so, s/he will access the rights and duties of the host country, and hence undertake a socialisation process into the host country, but not an assimilation. The immigrant will be integrated in some areas (labour market, housing market etc.), but not fully. The children of the immigrants will grow up with the institutions of the host country, and consequently be more socialised in the host country than their parents are. Language and socialisation are not enough to be integrated. This requires assimilation, and hence the integration will only be partial if the immigrant and their children are unwilling to align themselves with the majority population.

The situation labelled as 'incomplete' integration will lead to integration or assimilation, but, according to several theories, the process may take quite some time. The Chicago school assimilation theory claims it will take three generations to become part of a new community (Park 1950; Thomas and
Znaniecki 1974). Assimilation is assumed a linear process in which the immigrants will align to the natives over time. First generation immigrants are culturally different upon arrival but assimilate to some degree towards the dominant culture. Their children will grow up and be socialised within a society that is different from that of their parents' home country. The majority culture will be their native culture, though they may still adhere to some values and practices of their parents' native culture while at home and within their community if that community is predominantly composed of a homogenous immigrant group. The grandchildren of the original immigrants are less likely to maintain aspects of their grandparents' culture and language and are likely to be culturally indistinguishable from the majority culture (Oswald 2007).

The melting pot theory is often used to describe the assimilation of immigrants into the United States. It is a monocultural metaphor for explaining a heterogeneous society becoming more homogeneous with different elements 'melting together' into a harmonious whole with a common culture, or vice versa, for a homogeneous society becoming more heterogeneous through the influx of foreign elements with different cultural backgrounds and a potential for disharmony with the previous culture (Gordon 1964: Glazier and Moynihan 1964; Oswald 2007).

Immigrants with a strong national identity will find it difficult to integrate into the host country as they already carry a national culture from their country of origin. They may even consider the lifestyle in the host country as perhaps decadent or sinful. Although the host country requires that the immigrant learn the language in order to enjoy the rights and duties of the new country and show a willingness to become socialised into the host country, this may be difficult for the immigrant. In cases where the migrant is a refugee, s/he may not want to be in the host country to start with, and instead the immigrant clings on the country of origin. That such an integration will be slow and even take generations is not surprising.

The theoretical situation where both the nationality of the immigrant and host country is based upon language and socialisation is assumed to lead to a fast and successful integration. Canada is an example for this particular type of integration institution as it is seen as a raw-model for

Table 1 Perceptions of nationality by immigrants and host countries and their implications on integration

\begin{tabular}{|c|c|c|c|}
\hline & & \multicolumn{2}{|l|}{ Immigrant } \\
\hline & & $\begin{array}{l}\text { Nationality by ethnicity, religion } \\
\text { and history }\end{array}$ & $\begin{array}{l}\text { Nationality by language } \\
\text { and socialisation }\end{array}$ \\
\hline \multirow[t]{2}{*}{ Country of residence } & Nationality by ethnicity, religion and history & No integration & Partial integration \\
\hline & Nationality by language and socialisation & Incomplete integration & Fast integration \\
\hline
\end{tabular}

Source: Own elaboration 
multiculturalism. The immigrant is assumed to keep his/her ethnical, religious or other cultural diversity, but is presumed to learn the language and adjust into the Canadian society (Oswald 2007). It is very explicit that the Canadian immigration law favours young, well-educated immigrants with relevant work experience, a high language proficiency in English, and a high likelihood of adaptability to Canadian society. For refugees, a huge number of programs and services are available to help those with refugee status become participating members of Canadian society as quickly as possible. Immigrants are selected according to their presumed ability to adjust to the new society, and as both parties understand what is required from them, a relatively fast integration of immigrants is expected. However, the increasing poverty rates seen among immigrants with refugee status indicates that their integration does not run as smoothly as with labour migrants (Reitz 2011).

The theoretical situation labelled as 'no integration' is absent in research literature. North (1990) and March and Olsen (1989) have pointed out the strong impact that informal institutions have on our daily lives, and in this article it is shown that that the integration of immigrants is also influenced by informal institutions. A majority portion of some immigrant groups seldom assimilates or even integrates into their host country. Previous research has identified that some immigrant groups are unwilling to integrate into new countries (Han 2010), thereby raising the question as to whether the integration of immigrants can be achieved if some immigrants turn their back on the host country. In other words, if the institutions surrounding nationality do not change, then there will be no integration when the nationality of the immigrant and host country is based upon ethnicity, religion and history. 'It takes two to tango', and in this scenario, it would seem that neither party wishes to dance.

\section{Beyond Theory}

As a theoretical exercise, it goes without saying that it needs to be tested with empirical data. Until then it presents a hypothesis on the relationship between (informal) institutions and the integration of immigrants. However, it is clear that an overwhelming majority of the theories used to explain integration and the assimilation of immigrants into new societies are based upon developments in North America. To what extent these theories are applicable to European conditions can be questioned, especially given that the welfare systems, labour markets etc. of Europe and North America work completely differently.

The discussion here suggests that informal institutions among natives and immigrants determine the integration of immigrants. This answers to the first research question.
The second research question can be answered as informal institutions can both explain why integrations take place, and why some nationalities integrate into a new country while others do not.

The answer to the third question is three-fold: (a) A failure to achieve an integration of immigrants in the host country will have consequences, including the marginalisation and social exclusion of immigrants in the form of e.g. housing segregation, labour market segregation, increased criminality and social problems, ethnic enclaves, political and religious radicalisation; and among natives, political (and religious) radicalisation, xenophobia and discrimination against immigrants are common issues (Han 2010). It is therefore important to address integration issues with adequate policy measures.

(b) In many countries where nationality is based upon ethnicity, religion and history, a demand for assimilation from its immigrants has been introduced (Doomernik and BruquetasCallejo 2016). However, such policies will be unlikely to lead to an assimilation of immigrants who have a nationality, which is based upon ethnicity, religion and history. These immigrants will presumably turn inward towards their own group, and this can lead to increased social exclusion, as well as political and religious radicalisation.

(c) The integration policies needed when the nationality of the immigrant and host country is based upon language and socialisation is, logically, completely different from those needed when the nationality of the immigrant and host country is based upon ethnicity, religion and history. The 'Canada' model focuses on language skills and socialisation into Canadian society, and is based on immigrants participation in the labour market. Since the policy is based upon an immigration of those who are likely to become easily integrated, the selection process avoids several integration problems. However, it must be remembered that the languages spoken in Canada - English and French - are languages taught and spoken all over the world. If smaller countries, e.g. Finland, Poland or Italy, copy the Canadian immigration and integration policy, the result would be different as significantly fewer people speak these languages to start with. These countries are traditionally emigration countries, and not, like Canada, USA or Australia, traditional immigration countries. Moreover, the social security nets in European welfare states are further reaching and more generous than seen in Canada, and so the social security systems in Europe provide less incentive for immigrants to be self-providing.

The two slow integration situations (partial and incomplete integration) have been highlighted by e.g. the Chicago school of assimilation, the melting pot theory, racial/ethnic disadvantage theory, and by perspectives of ethnic stratification and selective acculturation. These theories agree that integration 
takes a long time, and assimilation even longer. An integration of immigrants cannot be achieved by a quick-fix policy launched by politicians who want to solve the integration problems during the current electoral term.

The outlined institutional approach appears to offer a promising theoretical tool to explain immigrant integration, as well as its failure. Empirical examinations of the hypotheses generated by this article will reveal if this is the case or not.

Funding Information Open access funding provided by University of Eastern Finland (UEF) including Kuopio University Hospital.

Open Access This article is licensed under a Creative Commons Attribution 4.0 International License, which permits use, sharing, adaptation, distribution and reproduction in any medium or format, as long as you give appropriate credit to the original author(s) and the source, provide a link to the Creative Commons licence, and indicate if changes were made. The images or other third party material in this article are included in the article's Creative Commons licence, unless indicated otherwise in a credit line to the material. If material is not included in the article's Creative Commons licence and your intended use is not permitted by statutory regulation or exceeds the permitted use, you will need to obtain permission directly from the copyright holder. To view a copy of this licence, visit http://creativecommons.org/licenses/by/4.0/.

\section{Further Reading}

Anton, H. 1999. Calculus with analytic geometry. New York:Wiley.

Bean, F. D., \& Stevens, G. 2003. America's newcomers: Immigrant incorporation and the dynamics of diversity. New York:Russel Sage Foundation.

de Cillia, R. 2012. Migration und Sprache/n. Sprachenpolitik Sprachförderung - Diskursanalyse. In H. Fassmann, \& J. Dahlvik (Eds.), Migrations- und Integrationsforschung - Multidiziplinäre Perspektive. Göttingen: Vienna University Press.

Doomernik, J., \& Bruquetas-Callejo, M. 2016. National Immigration and integration policies in Europe since 1973. In B. Garcés-Mascareñas, \& R. Penninx (Eds.), Integration processes and policies in Europe. Cham: Springer Open.

Esser, H. 2010. Assimilation, ethnic stratification, or selective acculturation? Recent theories of the integration of immigrants and the model of intergenerational integration. Sociologia: Italian Journal of Sociology Online, 4(1), 1-29.

Glazer, N. 1993. Is assimilation dead? Annals of the American Academy of Political and Social Science, 530(1), 122-136.

Glazer, N., \& Moynihan, D. P. 1963. Beyond the melting pot: The negroes, Puerto Ricans, Jews, Italians, and Irish of New York City. Cambridge:MIT Press.

Gordon, M. M. 1964. Assimilation in American life. In The role of race, religion and National Origin. New York: Oxford University Press.

Han, P. 2010. Soziologie der Migration. Stuttgart:Lucius \& Lucius.

Hansen, R. 2012. The centrality of employment in immigrant integration in Europe. Washington, DC:Migration Policy Institute.

Heckmann, F., \& Bosswick, W. 2006. Integration of migrants: Contribution of local and regional authorities. Dublin:European Foundation for the Improvement of Living and Working Conditions.

Hobsbawm, E. J. 1995. Nations and nationalism since 1780. Cambridge: Cambridge University Press.
Hobsbawm, E. J., \& Ranger, T. (Eds.) 1983. The invention of traditions. Cambridge:Cambridge University Press.

Hoekstra, M., Kohlbacher, J., \& Rauhut, D. 2017. Migration governance in three European cities: New local paradigms? In T. Lacroix, \& A. Desille (Eds.), International migrations and new local governance. New York: Palgrave.

Huber, P. 2014. What Institutions help immigrants integrate? WWWforEurope working paper no. 77. Available from https:// ideas.repec.org/b/wfo/wstudy/57884.html

IOM 2011. Glossary on migration. In International migration law no 25. Geneva: International Organisation of Migration.

Kingston, C., \& Caballero, G. 2009. Comparing theories of institutional change. Journal of Institutional Economics, 5(2), 151-180.

Kogan, I. 2007. Working through barriers. Host country institutions and immigrant labour market performance in Europe. Heidelberg:Springer.

Kristov, L., Lindert, P., \& McClelland, R. 1992. Pressure groups and redistribution. Journal of Public Economics, 48(2), 135-163.

Lee, J., \& Bean, F. D. 2004. America's changing color lines: Race/ethnicity, immigration, and multiracial identification. Annual Review of Sociology, 30(1), 221-242.

Lindert, P. H. 2004. Growing public. Social spending and economic growth since the eighteenth century. Cambridge:Cambridge University Press.

March, J. G., \& Olsen, J. P. 1986. Popular sovereignty and the search for appropriate institutions. Journal of Public Policy, 6(4), 341-370.

March, J. G., \& Olsen, J. P. 1989. Rediscovering institutions. The organizational basis of politics. New York:Free Press.

Martone, J., Zimmerman, D., Vidal de Haymes, M., \& Lorentzen, L. 2014. Immigrant integration through mediating social institutions: Issues and strategies. Journal of Community Practice, 22(3), 299-323.

Milgrom, P., North, D., \& Weingast, B. 1990. The role of institutions in the revival of trade: The law merchant, private judges and the champagne fairs. Economics \& Politics, 2(1), 1-23.

Mügge, L., \& van der Haar, M. 2016. Who is an immigrant and who requires integration? Categorizing in European policies. In B. Garcés-Mascareñas, \& R. Penninx (Eds.), Integration processes and policies in Europe. Springer Open: Cham.

North, D. 1990. Institutions, institutional change and economic performance. Cambridge:Cambridge University Press.

North, D. 1991. Institutions. Journal of Economic Perspectives, 5(1), 97-112.

OECD 2006. From immigration to integration. Paris:OECD.

Oswald, I. 2007. Migrationssoziologie. Konstanz:UVK Verlagsgesellschaft $\mathrm{mbH}$.

Paas, T., \& Halapuu, V. 2012. Attitudes towards immigrants and the integration of ethnically diverse societies. Norface migration discussion paper no. 2012-23 Available from http://www.norfacemigration.org/publ uploads/NDP 23 12.pdf

Park, R. E. 1950 [1926]. Race and culture: Essays in the sociology of contemporary man. New York:The Free Press of Glencoe.

Penninx, R. 2003. Integration: The role of communities, institutions and the state. Migration Policy Institute, October 1, 2003, www. migrationpolicy.org [retrieved: 18 October 2019]

Penninx, R., \& Garcés-Mascareñas, B. 2016. The concept of integration as an analytical tool and policy concept. In B. Garcés-Mascareñas, \& R. Penninx (Eds.), Integration processes and policies in Europe. Springer Open: Cham.

Piore, M. J. 1979. Birds of passage. New York:Cambridge University Press.

Polak, R. 2012. Religion im Kontext von Migration: mehr als ein integrationsfaktor. In H. Fassmann, \& J. Dahlvik (Eds.), Migrations- und Integrationsforschung - Multidiziplinäre Perspektive. Göttingen: Vienna University Press. 
Portes, A., \& Zhou, M. 1993. The new second generation: Segmented assimilation and its variants. The Annals of the American Academy of Political and Social Science, 530(1), 74-96.

Reitz, J. G. 2011. En kritisk granskning av Kanadas exempel. In P. Hojem, \& M. Ådahl (Eds.), Kanadamodellen. Fores: Stockholm.

Rubin, A., \& Babbie, E. R. 2014. Research methods for social work. Andover:Cengage.

Scholten, P. 2016. Between National Models and multi-level decoupling: The pursuit of multi-level governance in Dutch and UK policies towards migrant incorporation. Journal of International Migration and Integration, 17(4), 973-994.

Scholten, P., \& Penninx, R. 2016. The multilevel governance of migration and integration. In B. Garcés-Mascareñas, \& R. Penninx (Eds.), Integration processes and policies in Europe. Cham: Springer.

Scholten, P., Collett, E., \& Petrovic, M. 2016. Mainstreaming migrant integration? A critical analysis of a new trend in integration governance. International Review of Administrative Sciences, 83(2), 283-302.

Scott, W. R. 2008. Institutions and organizations: Ideas and interests. Los Angeles:Sage.

Smith, A. D. 1996. Nations and nationalism in a global era. Bristol: Polity Press.
Spehar, A., Hinnfors, J., \& Bucken-Knapp, G. 2017. Passing the Buck: The case of failing multilevel governance and vulnerable EU migrants in Sweden. Nordic Journal of Migration Research, 7(2), 114-123.

Thomas, W. I., \& Znaniecki, F. 1974. The polish peasant in Europe and America. New York:Octagon Books.

Tullock, G. 2006. The vote motive. London:The Institute of Economic Affairs.

Waters, M. 1990. Ethnic options: Choosing identities in America. Berkeley:University of California Press.

Publisher's Note Springer Nature remains neutral with regard to jurisdictional claims in published maps and institutional affiliations.

Daniel Rauhut is associate professor and holds a $\mathrm{PhD}$ in Economic History from Lund University, Sweden. He has worked with issues related to migration and immigrants' integration for 20 years at universities in Sweden, Norway and Finland. This study is funded by the Horizon 2020 project 'Matilde', Grant Agreement No. 870831. 